\title{
Review and Prospect of Preschool Education Degree Authorization Institutions Construction in Mainland China
}

\author{
You $\mathrm{Xu}$ \\ School of Teacher Education \\ Jiangsu University \\ Zhenjiang, China
}

\author{
Haoru Zhang \\ School of Teacher Education \\ Jiangsu University \\ Zhenjiang, China
}

\begin{abstract}
After the founding of new China, the subject construction of preschool education in colleges and universities has gone through a course of seventy years. The number of authorized institutions for bachelor's degree has grown to three hundred fifty-six, which radiates to most prefecture-level administrative regions in mainland China. The number of authorized institutions matches the comprehensive expectation of all regions. In the next stage, attention should be paid to improving the quality of education and teaching of the existing authorized institutions.
\end{abstract}

Keywords-preschool education; discipline construction; academic degree authorization institutions; econometric analysis

\section{INTRODUCTION}

Discipline construction is the key to running higher education. The advanced nature and scientific nature of subject structure is the great power source of university development, and the number and layout of degree authorized colleges is the direct response of the whole development level of discipline. In mainland China, a threetier degree awarding system for bachelors, masters and doctors is implemented. This study focuses on the construction and distribution of the authorized institutions for bachelor's degree.

Discipline and professional construction are mutually based and complementary. The birth of China's preschool education related major in higher education is marked by the opening of nanny workshops in Beijing Female Higher Normal College in 1916. The development of preschool education in China has experienced a leap from 'nanny class' to 'preschool education major'. (CHEN Guomei, 2017) Master's degree awarding point has been built from scratch and the number of specialized undergraduate colleges grew to 324. However, the number and quality of kindergarten teachers in China is not enough, the training pressure of preschool professionals is obvious. (HONG Xiumin, JIANG Liyun, 2018) Building more and better degree authorization colleges is still an important focus of preschool education discipline construction. At present, the study of distribution of preschool education resources (FENG Wenquan, et, 2016) and the level of comprehensive development and interprovincial development differences (Chen Chunjin, Fan
Jieqiong, 2018) have been published. However, the research on degree authorization colleges, training institution of preschool education teachers in China, is rare, while the higher education discipline which belongs to the second discipline of pedagogy discipline has accumulated much experience in this research field.

The development of degree authority institutions can be viewed from two dimensions: history and geography. The basic element of history is time, and the basic element of geography is space. Based on the econometric analysis of preschool education degree-authorized institutions, the study is divided into 31 provincial districts in the mainland of China in the space of seventy years since the founding of the People's Republic of China.

\section{Materials, Methods And Analysis}

In June 1952, China began to adjust its departments after the system of higher education in the Soviet Union. It points out that the Education Department of Higher Normal School should have two departments, namely, school education discipline and preschool education discipline. Its task is to train the middle school teachers that the preschool education major was born in normal universities. The Department of Childcare of Beijing Normal University was incorporated into the Department of Education and was called Preschool Education Major, the related majors of University of Nanking, Fudan University, Lingnan University have been merged into the Nanjing Normal College's Department of Preschool Education newly established. By 1987, there were 22 universities in mainland China established department of preschool education. In the late 1990s, the scale of higher education in China developed rapidly. Since 2014, there are 94 new degree-authorized institutions of bachelor degree have been established, including private colleges and newly established public colleges. It can be seen as positive feedback from higher education on national policies and the demand markets for preschool education teachers.

Education is a subsystem of society. The development of education have been limited and influenced by a good many factors like politics, economics and cultures, etc. Professor Pan further believes the political, economic, cultural and demographic factors that influence the distribution of higher 
education in China. Based on the reliability of variable data sources, the main factors that affect the layout of the authorized institutions of preschool education bachelor degree in china can be used as 'Gross Domestic Product (GDP)', 'Total Expenditure on Education', 'Total Regional Population', 'Number of Institutions of Higher Learning', 'Number of High School Students' and 'Number of Children in Kindergarten'. 'Gross Domestic Product (GDP)' and 'Total Expenditure on Education' correspond to the economic basis for educational undertakings, 'Total Regional Population' represents the overall situation of the regional population, 'Number of High School Students' represents the possible number of students who are eligible for undergraduate study. 'Number of Institutions of Higher Learning' can directly reflect the development of higher education in the region. 'Number of Children in Kindergarten' can determine the number of kindergarten teachers in a region. At present, the regional distribution and variable information of authorized institutions of preschool education bachelor in mainland China are shown in "Table I".

TABLE I. INFORMATION OF AUTHORIZED INSTITUTIONS OF PRESCHOOL EDUCATION BACHELOR

\begin{tabular}{|c|c|c|c|c|c|c|c|}
\hline Regions & $\begin{array}{l}\text { Gross Domestic } \\
\text { Product } \\
\text { (thousands yuan) }\end{array}$ & $\begin{array}{c}\text { Total Expenditure } \\
\text { on Education } \\
\text { (thousands yuan) }\end{array}$ & $\begin{array}{c}\text { Total Regional } \\
\text { Population } \\
\text { (thousands person) }\end{array}$ & $\begin{array}{c}\text { Number of } \\
\text { Institutions of } \\
\text { Higher Learning } \\
\text { (pieces) }\end{array}$ & $\begin{array}{c}\text { Number of High } \\
\text { School Students } \\
\text { (person) }\end{array}$ & $\begin{array}{c}\text { Number of } \\
\text { Children in } \\
\text { Kindergarten } \\
\text { (person) }\end{array}$ & $\begin{array}{c}\text { Authorized } \\
\text { Institutions } \\
\text { (pieces) }\end{array}$ \\
\hline Northern China & 11220508000 & 470706890 & 174790 & 403 & 2774463 & 4749328 & 51 \\
\hline Northeast China & 5425645000 & 229833510 & 108750 & 258 & 1599902 & 1968535 & 32 \\
\hline Eastern China & 32011156000 & 1098716180 & 408980 & 791 & 6219556 & 13181698 & 98 \\
\hline Mid-south China & 22662491000 & 9335218900 & 393010 & 631 & 7060156 & 15217911 & 84 \\
\hline Southwest China & 8763304000 & 505636560 & 200950 & 328 & 3918704 & 6618686 & 56 \\
\hline Northwest China & 4630906000 & 288146820 & 101860 & 220 & 2173703 & 4265235 & 35 \\
\hline
\end{tabular}

The specific data of each provincial administrative region were input into SPSS19.0 for Pearson's correlation coefficient analysis. It is assumed that there is a linear correlation between the layout of authorized institutions and the above six influencing factors. As shown in "Table II", the number of authorized institutions for bachelor's degree is significantly correlated with 'Gross Domestic Product (GDP)', 'Total Expenditure on Education', 'Total Regional Population', 'Number of Institutions of Higher Learning', 'Number of High School Students' and 'Number of Children in Kindergarten' at the level of 0.01 (bilateral).

TABLE II. PEARSON's CORRELATION COEFFICIENT MATRIX

\begin{tabular}{|c|c|c|c|c|c|c|c|c|}
\hline & & \begin{tabular}{|c|} 
Gross Domestic \\
Product \\
(thousands yuan)
\end{tabular} & \begin{tabular}{|c|} 
Total \\
Expenditure \\
on Education \\
(thousands \\
yuan)
\end{tabular} & $\begin{array}{l}\text { Total Regional } \\
\text { Population } \\
\text { (thousands } \\
\text { person) }\end{array}$ & \begin{tabular}{|c|} 
Number of \\
Institutions of \\
Higher \\
Learning \\
(pieces)
\end{tabular} & \begin{tabular}{|c} 
Number of \\
High School \\
Students \\
(person)
\end{tabular} & $\begin{array}{c}\text { Number of } \\
\text { Children in } \\
\text { Kindergarten } \\
\text { (person) }\end{array}$ & $\begin{array}{c}\text { Authorized } \\
\text { Institutions } \\
\text { (pieces) }\end{array}$ \\
\hline \multirow{3}{*}{$\begin{array}{l}\text { Gross domestic Product } \\
\quad \text { (thousands yuan) }\end{array}$} & Pearson's & 1 & $.953^{* * *}$ & $.847^{* *}$ & $853^{* *}$ & $.678^{* *}$ & $.779^{* *}$ & $.545^{* *}$ \\
\hline & Significance & & .000 & .000 & .000 & .000 & .000 & .002 \\
\hline & $N$ & 31 & 31 & 31 & 31 & 31 & 31 & 31 \\
\hline \multirow{2}{*}{$\begin{array}{c}\text { Total Expenditure on } \\
\text { Education } \\
\text { (thousands yuan) }\end{array}$} & Pearson's & $.953^{* *}$ & 1 & $.916^{* *}$ & $865^{* *}$ & $807^{\text {** }}$ & $882^{* *}$ & $615^{* *}$ \\
\hline & $N$ & 31 & 31 & 31 & 31 & 31 & 31 & 31 \\
\hline \multirow{3}{*}{$\begin{array}{c}\text { Total Regional } \\
\text { Population } \\
\text { (thousands person) }\end{array}$} & Pearson's & $.847^{* *}$ & $.916^{* *}$ & 1 & $.906^{* *}$ & $.945^{* *}$ & $.943^{* *}$ & $.774^{* * *}$ \\
\hline & Significance & .000 & .000 & & .000 & .000 & .000 & .000 \\
\hline & $N$ & 31 & 31 & 31 & 31 & 31 & 31 & 31 \\
\hline \multirow{3}{*}{$\begin{array}{c}\text { Number of Institutions of } \\
\text { Higher Learning } \\
\text { (pieces) }\end{array}$} & Pearson's & $.853^{* *}$ & $.865^{* *}$ & $.906^{* *}$ & 1 & $.784^{* *}$ & $.801^{* *}$ & $.750^{* *}$ \\
\hline & Significance & .000 & .000 & .000 & & .000 & .000 & .000 \\
\hline & $N$ & 31 & 31 & 31 & 31 & 31 & 31 & 31 \\
\hline \multirow{2}{*}{$\begin{array}{c}\text { Number of High School } \\
\text { Students } \\
\text { (person) }\end{array}$} & Pearson's & $.678^{* *}$ & $.807^{\text {** }}$ & $.945^{* *}$ & $.784^{* *}$ & 1 & $.957^{* *}$ & $.783^{* *}$ \\
\hline & $N$ & 31 & 31 & 31 & 31 & 31 & 31 & 31 \\
\hline \multirow{3}{*}{$\begin{array}{c}\text { Number of Children in } \\
\text { Kindergarten } \\
\text { (person) }\end{array}$} & Pearson's & $.779^{* *}$ & $.882^{* *}$ & $.943^{* *}$ & $.801^{* *}$ & $.957^{* *}$ & 1 & $.728^{* *}$ \\
\hline & Significance & .000 & .000 & .000 & .000 & .000 & & .000 \\
\hline & $N$ & 31 & 31 & 31 & 31 & 31 & 31 & 31 \\
\hline \multirow{3}{*}{$\begin{array}{c}\text { Authorized Institutions } \\
\text { (pieces) }\end{array}$} & Pearson's & $.545^{* *}$ & $.615^{* *}$ & $.774^{* *}$ & $.750^{* *}$ & $.783^{* *}$ & $.728^{* *}$ & 1 \\
\hline & Significance & .002 & .000 & .000 & .000 & .000 & .000 & \\
\hline & $N$ & 31 & 31 & 31 & 31 & 31 & 31 & 31 \\
\hline
\end{tabular}

And the Pearson's correlation coefficients are 0.545 , $0.615,0.774,0.750,0.783$ and 0.728 . It can be concluded that there is a strong positive collinearity between the number of authorized institutions of preschool education bachelor degree and these six variables. The degree of collinear fitting between the number of professional institutions and the number of high school students is the highest, and the degree of collinear fitting between the number of regional total population and the number of colleges and universities is the second and third respectively. 
However, the Pearson's correlation coefficient analysis can only explain the correlation, can't reflect causation.

After verifying that the six factors are all related to the establishment of preschool education undergraduate professional institutions and all present positive collinearity, the above six factors variables can be processed as a unit. The relevant variables of the six regions are sorted by absolute values, and the region with the absolute value of each factor variable is defined as unit 1 , and then the absolute values of other large regions are converted into units, and regional expectation values corresponding to the six factor variables are generated. And the final regional comprehensive expected distribution is presented as: Northern China: Northeast China: Eastern China: Mid-south China: Southwest China: Northwest China= 0.125: 0.066: 0.307: 0.286: 0.137: 0.080. (See "Table III")

TABLE III. DEgREe Authorizing InStitution Single FACTOR VARIABLE EXPECTATION Distribution

\begin{tabular}{|c|c|c|c|c|c|c|}
\hline Factor variables & Northern China & Northeast China & Eastern China & Mid-south China & Southwest China & Northwest China \\
\hline Gross Domestic Product & 2.423 & 1.172 & 6.913 & 4.894 & 1.892 & 1.000 \\
\hline Total Expenditure on Education & 2.048 & 1.000 & 4.780 & 4.062 & 2.200 & 1.254 \\
\hline Total Regional Population & 1.716 & 1.068 & 4.015 & 3.858 & 1.973 & 1.000 \\
\hline $\begin{array}{l}\text { Number of Institutions of Higher } \\
\text { Learning }\end{array}$ & 1.832 & 1.173 & 3.595 & 2.868 & 1.491 & 1.000 \\
\hline Number of High School Students & 1.734 & 1.000 & 3.887 & 4.413 & 2.449 & 1.359 \\
\hline $\begin{array}{l}\text { Number of Children in } \\
\text { Kindergarten }\end{array}$ & 2.413 & 1.000 & 6.696 & 7.731 & 3.362 & 2.167 \\
\hline
\end{tabular}

The current actual degree authorizing institutions accounted for Northern China: Northeast China: Eastern China: Mid-south China: Southwest China: Northwest China=45 : $28: 88: 80: 52: 31=0.139: 0.086: 0.272:$ $0.247: 0.160: 0.096$. Single-sample nonparametric chisquare test based on regional expected value distribution ratio, the number of preschool education undergraduate majors distributed to the regional expectations is 40.5: 21.4 : 99.4: 92.6: 44.3: 25.9. (See "Table IV" and "Table V")

TABLE IV. DISTRICT EXPECTATIONS OF THE BACHELOR'S DEGREE AUTHORITY

\begin{tabular}{|l|l|l|l|}
\hline & Observed data & Expected number & Residual \\
\hline Northern China & 51 & 44.5 & 6.5 \\
\hline Northeast China & 32 & 23.5 & 8.5 \\
\hline Eastern China & 98 & 109.2 & -11.2 \\
\hline Mid-south China & 84 & 101.7 & -17.7 \\
\hline Southwest China & 56 & 48.3 & 7.3 \\
\hline Northwest China & 35 & 28.5 & 6.5 \\
\hline Total & 356 & & \\
\hline
\end{tabular}

"Table V" is the test statistics of chi-square test and the corresponding $\mathrm{P}$ value, where the $\mathrm{P}$ value is $0.054>0.05$. Therefore, it can be concluded that there is no significant difference in the number of inter-regional layout of preschool education degree authorized institutions in mainland China. That is to say, the current layout of the authorized institutions for bachelor's degree in preschool education in China is reasonable, and the actual number of authorized institutions in each region matches the comprehensive expectation ratio of each region.

TABLE V. TEST Statistics

\begin{tabular}{|l|l|}
\hline & Region \\
\hline chi-square & $10.886 \mathrm{a}$ \\
\hline df & 5 \\
\hline Asymptotic significance & .054 \\
\hline
\end{tabular}

\section{CONCLUSION}

Based on the statistics of politics, economy, population and other relevant factors, this study conducted a quantitative analysis on the authorized institutions of preschool education bachelor's degree in China, and drew the following conclusions. From the historical process, in mainland China preschool education bachelor's degree for the construction of the authority with the opening of the subjects adjustment in 1952 , along with the popularization of higher education in the early 21 century and college the rise of the rapid growth, and the form developed from a single normal nature undergraduate extend into containing non normal undergraduate and Chinese-foreign cooperation in running schools, and other forms.

From the perspective of geographical division, the construction of authorized institutions of preschool education bachelor's degree in mainland China takes the regional central normal university as the key point, the local provincial normal university and local normal university as the pioneering point, and the private independent college and private college as the new growth points. At present, the distribution of bachelor's degree accrediting institutions in preschool education is balanced among regions, and the number of degree accrediting institutions in each region matches the comprehensive expectation of each region. However, in terms of the total amount, the establishment of authorized institutions of preschool education bachelor's degree has not fully met the needs of preschool education institutions such as kindergartens, and the number still needs to be improved. It is necessary to accelerate the pace of the establishment of degree-granting institutions and promote the rapid and healthy development of preschool education in China.

\section{REFERENCES}

[1] Hong Xiumin; Jiang Liyun; The Problems, Causes and Countermeasures of the Development of Chinese Early Childhood 
Education under the Two-Child Policy - An Analysis of Phase 2 Three-Year Action Plan for Early Childhood Education. Journal of Beijing Normal University (Social Sciences). 2018, 53-61.

[2] Feng Wenquan; Xu Songni; Gao Jing; Causes and Solutions of the Regional Imbalance of Preschool Education Development. Journal of Southwest University (Social Sciences Edition). 2016, 42, 75-84+190.

[3] Chen Chunjin; Fan Jieqiong; Interprovincial Comparisons of the Comprehensive Development of Preschool Education in China. Studies in Early Childhood Education. 2018, 14-27. 